\title{
Pest Management in the United States Greenhouse and Nursery Industry: I. Trends in Chemical and Nonchemical Control
}

\author{
Melvin P. Garber ${ }^{1}$, \\ William G. Hudson?2, \\ Jeffrey G. Norcini ${ }^{3}$, \\ Ronald K. Jones ${ }^{4}$, \\ Ann R. Chase ${ }^{5}$, and \\ Kane Bondari ${ }^{6}$
}

Additional index words. ornamentals, extension service, information sources, IPM

Summary. A national survey of the greenhouse and nursery industries was conducted to determine the current status of pest management practices. This study covers the trends in chemical and nonchemical pest control measures and

${ }^{1}$ Associate professor and extension horticulturist University of Georgia, P.O. Box 1209, Tifton, GA 31793.

${ }^{2}$ Associate professor and extension entomologist University of Georgia, P.O. Box 1209, Tifton, GA 31793.

${ }^{3}$ Associate professor, University of Florida Research and Education Center, Route 4, Box 4092, Monticello, FL 32344-9304.

${ }^{4}$ Professor and extension plant pathologist, North Carolina State University, Raleigh, NC 27695.

${ }^{5}$ Emeritus professor of plant pathology, Central Florida Research and Education Center, University of Florida, Apopka, FL 32703.

${ }^{6}$ Professor, Department of Statistical and Computer Service, Coastal Plain Experiment Station, Tifton GA 31793.

The cost of publishing this paper was defrayed in part by the payment of page charges. Under postal regulations, this paper therefore must be hereby marked advertisement solely to indicate this fact. 
factors that affect adoption of nonchemical control measures. For the 5-year period 1988-93, there appeared to be a decrease in chemical use for disease and insect control and for plant growth regulators. During the same period there was an increase in chemical weed control. The adoption of nonchemical pest control measures was concentrated in the area of insect control. The primary factors limiting use of nonchemical pest control measures were 1) availability of effective materials/ biological agents, 2) availability of information, and 3) management complexity. The primary information sources on nonchemical pest control used by growers varied by size of firm and region of the country. For all respondents the primary sources were 1) industry trade journals, 2) other growers in the industry, 3) cooperative extension service, and 4) industry-sponsored seminars.

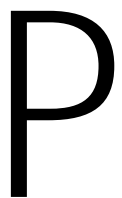

est control methods have changed periodically over the years in response to sociologic and scientific developments. When theornamentals industry started in the early 1900s, many pest control methods were based on cultural controls such as use of pest-free planting material, environmental manipulation, and inorganic pesticides such as sulfur and copper. During the 1960s, many new synthetic pesticides became available and revolutionized theornamental sindustry. These pesticides were highly effective, target specific, and easier to use than previously available products. These newer pesticides allowed a higherquality, less expensive product to be distributed throughout the world. During the past 10 years, biological products (Aylsworth, 1994; Gill, 1994; Heinz and Parrella, 1994), improved environmental management techniques such as insect screening (Gill and Ross, 1994), accurate humidity (Onofrey, 1994), light, and temperature controls,

Table 1. Trends in national use of chemical pest control measures in the ornamentals industry.

\begin{tabular}{llcc}
\hline & \multicolumn{3}{c}{ Use $^{z}$ (\% response) } \\
\cline { 2 - 4 } Control measure & Less $^{y}$ & Same & More $^{x}$ \\
\hline Chemical insecticides & 42.8 & 35.6 & 21.6 \\
Chemical fungicides/bactericides & 36.4 & 43.4 & 20.2 \\
Chemical herbicides & 24.0 & 43.5 & 32.5 \\
Chemical plant growth regulators & 31.8 & 52.5 & 15.7 \\
\hline
\end{tabular}

${ }^{2}$ Respondents were asked to rate their use of chemical pesticides in 1993 compared to 1988.

yCombined response for much less and little less.

${ }^{x}$ Combined response for much more and little more.

and computerized irrigation systems have altered further the balance of pest control methods in the ornamental industry.

Pesticide use patterns have continued to changeduring the past 5 to 10 years. Decreased or lost availability of industry standards such as methyl bromide (Whitten, 1994), benomyl, oxydemeton-methyl, and Pirimicarb, to name a few, have forced a shift to less-effective products as well as nonchemical methods of pest control. New earth-friendly (Robb, 1994) products, such as silicon for Pythium control (Lawson, 1994), an extract from hot peppers for insect control (Chadwick, 1994), and insect growth regulators (IGRs) (Oetting, 1994), currently are being researched and tested by many ornamental producers. Finally a dramatic shift in public opinion regarding pesticide use has forced all segments of theagricultural industry to review their methods of pest control.

Business analyses of various segments of the Florida ornamentals industry have been published over the years, indicating the relative costs of operating a nursery, including pest control (Hodges, 1991; Hodges and Hull, 1991). They reported pesticide costs at $1.5 \%$ of production for large firms and $2.7 \%$ for small firms for central Floridafoliagenurseries (Hodges and Hull, 1991). These costs were $3.2 \%$ and $2.1 \%$ for large and small firms producing foliage plants in south ern Florida. Similar findings were obtained for container woody ornamental nurseries; large nurseries reported $2.6 \%$, whereas small nurseries re- ported 1.2\% (Hodges, 1991). Largefield nurseries producing woody ornamentals reported only $1.7 \%$ used on pesticides and chemicals, while small field nurseries reported $1.7 \%$.

Moody and Halbrooks published results of a survey conducted to determine the benefits of various pest management systems in the southeastern United States in 1992. The survey results characterized the attitudes toward pest control. Most respondents reported using a combination of workers, management, and a pest manager to determine when to apply pest control treatments. Some form of spot treatment was most common, with little reliance on a threshold for each pest beforespraying. Most growers al so reported spraying on apreventativeprogram with $30 \%, 30 \%$, and $40 \%$ on a weekly, biweekly, or monthly schedule, respectively. Almost half of the respondents characterized use of pest control chemicals as routine.

Many professionals can report observational shifts in use of specific pest control methods, but a national study on the methods used in the ornamental greenhouse and nursery industry has not been conducted. This and the following four papers presents the results of a national survey conducted in 1994 to determine the status of pest management practices in the United States greenhouse and nursery industry. This study covers the trends in chemical and nonchemical pest control methods between 1988 and 1993. Theinformation sources and the limitations to implementation of alternative pest management practices also are discussed.

Table 2. Trends in regional use of chemical pest control measures.

\begin{tabular}{|c|c|c|c|c|c|c|c|c|c|c|c|c|}
\hline \multirow[b]{3}{*}{ Control measure } & \multicolumn{12}{|c|}{ Use $^{z}$ (\% response) } \\
\hline & \multicolumn{4}{|c|}{ Less } & \multicolumn{4}{|c|}{ Same } & \multicolumn{4}{|c|}{ More } \\
\hline & $1^{y}$ & II & III & IV & $\mathrm{I}$ & II & III & IV & 1 & II & III & IV \\
\hline Chemical insecticides & 41.9 & 44.1 & 42.5 & 42.3 & 37.2 & 38.5 & 31.9 & 36.2 & 20.9 & 17.4 & 25.6 & 21.6 \\
\hline \multirow{2}{*}{\multicolumn{13}{|c|}{$\begin{array}{l}\text { Chemical fungicides/ } \\
\text { bactericides }\end{array}$}} \\
\hline & 38.6 & 43.3 & 36.6 & 24.2 & 46.2 & 38.0 & 38.6 & 54.7 & 15.2 & 18.7 & 24.8 & 21.1 \\
\hline Chemical herbicides & 25.7 & 19.8 & 26.5 & 23.3 & 38.9 & 51.3 & 36.5 & 48.8 & 35.4 & 28.9 & 37.0 & 27.9 \\
\hline \multicolumn{13}{|l|}{ Chemical plant growth } \\
\hline regulators & 29.1 & 39.5 & 28.8 & 28.7 & 56.3 & 44.1 & 60.1 & 50.5 & 43.7 & 16.4 & 11.0 & 20.8 \\
\hline
\end{tabular}

${ }^{z}$ Respondents were asked to rate their use of chemical pesticides in 1993 compared to 1988.

y'Region of the country as defined in materials and methods: I, northeastern; II, southeastern; III, north-central; IV, western. Number of respondents were northeastern (143), southeastern (209), upper midwestern (214), and western (134). 
Table 3. Very important factors affecting selection of pesticides.

\begin{tabular}{lccc}
\hline & \multicolumn{3}{c}{ Firm size $^{2}(\%$ response $)$} \\
\cline { 2 - 4 } Selection factor & Small & Medium & Large \\
\hline Cost & 24.7 & 23.5 & 33.9 \\
Effectiveness & 97.8 & 97.4 & 99.4 \\
Toxicity & 66.9 & 67.2 & 60.8 \\
Availability & 52.1 & 50.9 & 44.1 \\
Application method & 50.0 & 50.9 & 34.5 \\
Formulation (WP, DIF) & 23.7 & 22.9 & 17.5 \\
Environmental effects & 70.2 & 68.1 & 61.2 \\
\hline
\end{tabular}

'Size of firm based on 1993 sales: small ( $\$ 0-\$ 500,000)$; medium $(\$ 500,000-\$ 2,000,000)$, and large $(>\$ 2,000,000)$. Number of respondents were small (285), medium (225), large (165).

Table 4. Trends in national use of nonchemical pest control measures.

\begin{tabular}{lccc}
\hline & \multicolumn{3}{c}{ Use $^{\mathrm{z}}$ (\% response) } \\
\cline { 2 - 4 } Control measure & Less $^{\mathrm{y}}$ & Same & More $^{\mathrm{x}}$ \\
\hline Nonchemical insecticides & 10.8 & 44.9 & 44.4 \\
Nonchemical fungicides/bactericides & 13.7 & 66.5 & 19.8 \\
Nonchemical herbicides & 15.8 & 68.8 & 15.4 \\
Nonchemical plant growth regulators & 16.6 & 67.9 & 15.5
\end{tabular}

${ }^{2}$ Respondents were asked to rate their use of nonchemical pesticides in 1993 compared to 1988.

yCombined response for much less and little less.

${ }^{x}$ combined response for much more and little more.

The study addressed the following aspects of pest management practices in the greenhouse and nursery industry: a) thetrends in chemical and nonchemical pest control measures from 1988 to 1993 ; b) the factors that affect the selection of specific pesticides; $c$ ) the factors that limit the use of alternative pest management practices; and d) the importance of selected information sources about alternative pest management practices.

The study results should allow better targeting of new products, new services, and sources of information for the ornamentals industry. This study represents the first evaluation of the degree of knowledge, use, and efficacy of the full range of pest control methods currently available. Future research, extension, and allied industry efforts could use this type of information to serve the ornamentals industry and ensure effective use of pesticides.

\section{Materials and methods}

Survey questionnaires were mailed by the Univ. of Georgia to 1650 firms that were members of the grower divisions of the American Association of Nurserymen (1246/1650) or the Society of American Florists (404/1650). The initial mailing was sent in January 1994 with follow-up mailings to nonrespondents in February and March, 1994.

Eighthundred thirty responses were received from members of the American Association of Nurserymen (636/1246) and Society of American Florists (194/404) for a 50.3\% response rate. A total of 712 questionnaires (43.7\%) was completed sufficiently for analysis, although 12 did not include state. Responses were received from all states except Alaska, Montana, Wyoming, and Vermont.

Theresponses were segmented by thesize of firm and by United States region to understand factors affecting pest management practices in the United States greenhouse and nursery industry.

For analysis by firm size, firms weregrouped according to 1993 sales volume: small (\$0$\$ 500,000)$; medium $(\$ 500,001-\$ 2,000,000)$; and large $(<\$ 2,000,000)$.

For analysis by region, the country was divided into four geographic regions: northeast
ern(Pennsylvania, New York, Maryland, and Connecticut yielded $81 \%$ of responses for this region); southeastern (Florida, North Carolina, Tennessee, Virginia, and Texas yielded $70 \%$ of responses for this region); north-central (Ohio, Indiana, Michigan, and Minnesota yielded $83 \%$ of responses for this region); and western (California, Oregon, and Washington yielded $83 \%$ of responses for this region).

The frequency distribution of respondents was tabulated for each question with PROC FREQ of SAS (SAS Institute, Cary, N.C). Therelationship between firm size, region, and pesticide use was tested by chi-square and analysis of variance (ANOVA). Thetotal estimated regional use (pounds active ingredient) for each pesticide was determined by using USDA total sales for the greenhouse/nursery industry; the ratio of respondent sales to USDA sales was used to estimate total regional use.

\section{Results and discussion}

The respondents generally indicated that they were using less chemical pesticides in 1993 compared to 1988 (5 years before the survey). About twice as many respondents indicated the use of less insecticides, fungicides/bactericides, and plant growth regulators (Table 1) than respondents indicating use of more chemicals. Weed control was the exception, with $32.5 \%$ of respondents indicating use of more chemical herbicides compared to the $24.0 \%$ indicating use of less chemical herbicides. The respondents indicating use of less chemical pesticides ranged from $24.0 \%$ (weed control) to $42.8 \%$ (insect control).

The trends identified for the national use generally were reflected in the analysis by region (Table 2). There were also several regional differences. For instance, about $44 \%$ of therespondents in the northeastern region reported use of more chemical plant growth regulators compared to $29 \%$ reporting less use. Thepercentage of respondents reporting use of more chemical plant growth regulators was two to three times that reported in other regions. In all regions, the percentage of respondents using less insecticides and fungicides and bactericides exceeded that reporting more use of chemicals. In all regions the percentage of respondents using more herbicides exceeded that reporting less. Thereported use of less fungicide was about the same for the northeastern,

Table 5. Trends in regional use of less nonchemical pest control measures.

\begin{tabular}{lcccc}
\hline & \multicolumn{3}{c}{ Region (\% response) } \\
\cline { 2 - 4 } Control measure & Northeastern & Southeastern & North-central & Western \\
\hline Nonchemical insecticides & 9.0 & 16.0 & 9.6 & 7.4 \\
Nonchemical fungicides/bactericides & 11.9 & 20.2 & 13.6 & 6.9 \\
Nonchemical herbicides & 14.5 & 19.2 & 16.8 & 9.4 \\
Nonchemical plant growth regulators & 17.6 & 23.0 & 13.4 \\
\hline
\end{tabular}


Table 6. Factors that limit national use of alternative pest management practices.

\begin{tabular}{|c|c|c|c|c|}
\hline \multirow[b]{2}{*}{ Factor } & \multicolumn{4}{|c|}{ Degree of limitation (\% response) } \\
\hline & Not limiting & Somewhat limiting & Very limiting & Precludes use \\
\hline Cost & 15.5 & 59.5 & 22.8 & 2.2 \\
\hline Availability of materials/biological agents & 16.1 & 50.2 & 31.7 & 2.0 \\
\hline Effectiveness & 8.9 & 36.0 & 46.2 & 8.9 \\
\hline Lack of information & 15.6 & 40.0 & 38.8 & 5.6 \\
\hline Regulatory concerns & 32.1 & 34.1 & 27.9 & 5.9 \\
\hline Management complexity & 16.5 & 42.6 & 35.8 & 5.1 \\
\hline Labor requirements & 19.3 & 46.6 & 30.3 & 3.8 \\
\hline
\end{tabular}

southeastern, and north-central regions, with a much lower percentage of respondents in the western region reporting use of less fungicides (Table 2). Firm size did not affect the change in chemical pest control. This suggests that thetrends in chemical pest control may be influenced more by climate and crop selection than by firm size.

Factors that affect the selection of chemical pesticides were ranked according to the percentage of respondents choosing them as very important. In descending order of importance, the factors were effectiveness $(98 \%)$, environmental effects $(67 \%)$, toxicity $(66 \%)$, availability $(50 \%)$, application method (46\%), cost (27\%), and formulation (22\%). Theresponseto this question did not vary by region. Firms of all sizes agreed on the ranked importance of each factor, which was the same as for all firms combined. Several differences were observed among different size firms (Table3). The small and medium firms responded similarly. The large firms were more concerned with cost of the product and less concerned with toxicity, availability, application method, formulation, and environmental effects. Effectiveness of the pesticide was equally important to firms of all sizes and was the most important factor.

To obtain a better understanding of the pest management trends, especially the use of alternative control measures, respondents were asked to indicate the most recent 5-year trend in use of nonchemical control measures (Table4). Thearea of pest control in which nonchemical alternatives have been adopted most widely is insect control. About $44 \%$ of the respondents had used more nonchemical insect controlmeasures compared to nonchemical measures for control of disease $(20 \%)$ or weeds $(15 \%)$ or plant growth regulation $(16 \%)$. The tremendous gain in nonchemical insect control may bedue to increased avail ability of alternatives such as biological controls (Aylsworth, 1994; Gill, 1994; Heinz and Parrella, 1994) and screening (Gill and Ross, 1994). A review of the trade literature reveals the emphasis on nonchemical insect control (Oetting, 1994; Onofrey, 1994; Parrella, 1994; Robb, 1994; Whitten, 1994). There were no differences across size of firm and region in the use of more nonchemical control measures for insect control. Regional differences were apparent for the percentage of respondents using less nonchemical control measures. (Table5). The southeastern region reported the most respondents using less nonchemical control for all categories in 1993, compared to 1988 , and the west ern regionhad the fewest respondents using less nonchemical controls. This difference could be due in part to the warm humid climate in the southeastern region.

In an effort to understand the use of nonchemical control measures, respondents were asked to assess how much each of seven factors limit the adoption of alternative pest management practices (Table 6). The most limiting factors, as measured by percent responses of "very limiting", in descending order, were effectiveness (46\%), lack of information (39\%), management complexity $(36 \%)$, availability of materials/biological agents $(32 \%)$, labor requirements $(30 \%)$, regulatory concerns $(28 \%)$, and cost $(23 \%)$. The effectiveness of the alternative control measure was clearly the most important factor in adoption of nonchemical measures, especially when we consider that $9 \%$ of respondents indicated that lack of effectiveness would preclude use. The lack of information was another key limiting factor and one that is a major responsibility of university research and extension programs.

Analysis by region demonstrated some regional similarities and differences as to which factors were limiting the use of alternative pest management practices (Table 7). The most-limiting factor for all regions, with one-half to twothirds of therespondents rating it as "very limiting" or "precludes use", was the effectiveness of the alternative control measure. There was generally good agreement on the second (lack of information) and third (management complexity) mostlimiting factors. There was also good agreement that the least-limiting factor was cost (ranked seventh) and that regulatory constraints ranked near the bottom (fifth). Although the percent response was similar, the western region had availability of materials and biological agents as the third most limiting factor, while the southeastern and northeastern regions ranked this factor near the bottom, sixth. One explanation is that the western region is most advanced in adoption of alternative controls and has evaluated more of the available alternatives. In any case, the factors that are most limiting for a particular region should be considered when developing research and extension programs.

The analysis by size of firms provided addi-

Table 7. Factors that are very limiting or preclude use of alternative pest management practices.

\begin{tabular}{|c|c|c|c|c|c|c|c|c|}
\hline \multirow[b]{3}{*}{ Factor } & \multicolumn{8}{|c|}{ Region $^{2}$} \\
\hline & \multicolumn{2}{|c|}{ Northeastern } & \multicolumn{2}{|c|}{ Southeastern } & \multicolumn{2}{|c|}{ North-central } & \multicolumn{2}{|c|}{ Western } \\
\hline & $\%$ & Rank & $\%$ & Rank & $\%$ & Rank & $\%$ & Rank \\
\hline Cost & 18.1 & 7 & 27.5 & 7 & 27.1 & 7 & 25.2 & 6 \\
\hline \multicolumn{9}{|l|}{ Availability of materials/ } \\
\hline biological agents & 35.3 & 6 & 30.2 & 6 & 36.1 & 4 & 33.6 & 3 \\
\hline Effectiveness & 57.1 & 1 & 49.2 & 1 & 51.2 & 1 & 65.7 & 1 \\
\hline Lack of information & 46.6 & 2 & 44.5 & 3 & 44.6 & 2 & 41.3 & 2 \\
\hline Regulatory concerns & 37.5 & 5 & 34.0 & 5 & 35.5 & 5 & 26.7 & 5 \\
\hline Management complexity & 44.9 & 3 & 44.7 & 2 & 40.7 & 3 & 31.8 & 4 \\
\hline Labor requirements & 38.0 & 4 & 37.5 & 4 & 34.4 & 6 & 24.8 & 7 \\
\hline
\end{tabular}


Table 8. Factors that are very limiting or preclude use of alternative pest management practices.

\begin{tabular}{|c|c|c|c|c|c|c|}
\hline \multirow[b]{3}{*}{ Factor } & \multicolumn{6}{|c|}{ Firm size ${ }^{2}$} \\
\hline & \multicolumn{2}{|c|}{ Small } & \multicolumn{2}{|c|}{ Medium } & \multicolumn{2}{|c|}{ Large } \\
\hline & $\%$ & Rank & $\%$ & Rank & $\%$ & Rank \\
\hline Cost & 23.7 & 7 & 25.4 & 7 & 26.1 & 5 \\
\hline $\begin{array}{l}\text { Availability of materials/ } \\
\text { biological agents }\end{array}$ & 35.1 & 6 & 31.7 & 5 & 34.8 & 2 \\
\hline Effectiveness & 56.1 & 1 & 52.0 & 1 & 57.5 & 1 \\
\hline Lack of information & 50.8 & 2 & 46.8 & 2 & 31.9 & 4 \\
\hline Regulatory concerns & 42.8 & 4 & 31.2 & 6 & 23.2 & 6 \\
\hline Management complexity & 43.9 & 3 & 41.6 & 3 & 34.5 & 3 \\
\hline Labor requirements & 38.5 & 5 & 36.7 & 4 & 22.1 & 7 \\
\hline
\end{tabular}

zFirm size based on 1993 sales: small (\$0-\$500,000), medium (\$500,000-\$2,000,000), and large $(>\$ 2,000,000)$.

tional insight for the development of integrated pest management (IPM) programs when serving different size firms (Table 8). The small and medium firms generally agreed on how limiting each of the seven factors was for alternative pest management programs. The large firms agreed that effectiveness was the most limiting factor. However, their second rated factor was availability of materials and biological agents, which was rated fifth and sixth by medium and small firms, respectively. Since the alternatives are equally available to all firms, this suggests that largefirms havetried many of theavailablealternatives and their progress is more limited by availability of new alternatives. Extension programs focusing on small firms would need to emphasize what alternatives are available and how to implement these practices. Assisting large firms likely would require development of new alternatives that are easy to implement and manage.

There was good agreement across the four regions and generally for all size firms that availability of information was very important for the implementation of alternative pest management practices. To facilitate information transfer to the greenhouseand nursery industry, therespondents were asked to rate eight sources of information for frequency of use (Table 9). The most widely used sources, based on combined responses of "use a lot" and "primary source", in descending order ,wereindustry tradejournals (60\%), other growers in the industry (54\%), cooperative extension service $(47 \%)$, industry-sponsored seminars (45\%), university-sponsored seminars (34\%), chemical company representatives (34\%), scientific journals $(16 \%)$, and private consultants (15\%).

Therewas generally good agreement among different sized firms as to the most widely used sources of information on alternative pest management practices (Table 10). The ranking of the information was about the same, but there were interesting differences in the percent response by size of firm. For instance all size firms rated private consultants seventh or eighth in frequency of use. However the percentage of large firms that made extensive use of private consultants was 1.5 to 2.0 times that of medium and small firms, respectively. The financial ability of large firms to hire consultants may help explain their greater use. Also, the large volumes of pesticide purchases by the large firms could result in more service by the local chemical company representative. The use of theextension service decreases with an increasein size of the firm. The use of information by region reinforced the value of trade journals as a source of information on alternative pest management practices (Table 11). Thepercent responseand ranking was about the same across the four regions for university and industry seminars, respectively. The use of cooperative extension varied substantially by region with ahigh of $61 \%$ in thenortheastern region to a low of $32 \%$ in the western region.
Respondents in the western region also reported thelowest dependency on other growers. Respondents in the western region placed more emphasis on chemical company representatives and private consultants as sources of information for alternative pest management practices. The reliance on scientific journals was greatest in the southeastern region $(26 \%)$ and lowest in the western region $(10 \%)$, although the relative ranking of trade and scientific journals was similar for all regions.

\section{Implications for university research and extension programs}

Theinformation from the United States greenhouse and nursery industry provides valuable guidance for university research and extension programs. Well-focused university programs can enhance the value of university personnel as a vital resource for the greenhouse and nursery industry. This is the first study to identify the status of pest control measures on a national basis and to recommend directions for university programs. The results have several implications for university pest control programs.

1) The greatest progress in nonchemical pest control has occurred in the area of insect control. From 1988 to 1993, about $44 \%$ of the respondents used more nonchemical insect control measures (Table4) compared to nonchemical control of diseases $(20 \%)$,

Table 9. Information sources for alternative pest management practices.

\begin{tabular}{lcccc}
\hline & \multicolumn{3}{c}{ Importance (\% response) } \\
\cline { 2 - 5 } Source & Do not use & Use a little & Use a lot & Primary source \\
\hline Industry trade journals & 2.5 & 37.8 & 51.3 & 8.4 \\
Cooperative extension service & 8.5 & 44.4 & 35.1 & 3.0 \\
Industry-sponsored seminars & 11.0 & 43.6 & 39.2 & 6.2 \\
University-sponsored seminars & 18.8 & 47.0 & 29.6 & 4.6 \\
Private consultants & 56.8 & 27.8 & 44.8 & 3.9 \\
Other growers in industry & 3.4 & 42.5 & 13.9 & 9.3 \\
Scientific journals (HT, JEH) & 42.4 & 52.9 & 29.3 & 2.1 \\
Chemical company representatives & 13.0 & & 4.8 & \\
\hline
\end{tabular}


Table 10. Information sources for alternative pest management practices used by different sized firms.

\begin{tabular}{|c|c|c|c|c|c|c|}
\hline \multirow[b]{3}{*}{ Source } & \multicolumn{6}{|c|}{ Use a lot/primary source } \\
\hline & \multicolumn{2}{|c|}{ Small ${ }^{2}$} & \multicolumn{2}{|c|}{ Medium } & \multicolumn{2}{|c|}{ Large } \\
\hline & $\%$ & Rank & $\%$ & Rank & $\%$ & Rank \\
\hline Industry trade journals & 60.0 & 1 & 63.5 & 1 & 54.2 & 1 \\
\hline Cooperative extension service & 51.8 & 3 & 44.9 & 3 & 42.5 & 4 \\
\hline Industry-sponsored seminars & 44.8 & 4 & 44.5 & 4 & 45.8 & 3 \\
\hline University-sponsored seminars & 34.6 & 5 & 32.6 & 6 & 35.6 & 6 \\
\hline Private consultants & 9.5 & 8 & 16.5 & 7 & 23.5 & 7 \\
\hline Other growers in industry & 55.6 & 2 & 54.8 & 2 & 49.7 & 2 \\
\hline Scientific journals (HT, JEH) & 16.3 & 7 & 15.4 & 8 & 17.1 & 8 \\
\hline Chemical company representative & 30.3 & 6 & 33.7 & 5 & 38.9 & 5 \\
\hline
\end{tabular}

FFirm size based on 1993 sales: small (0-\$500,000), medium (\$500,000-\$2,000,000), and large (>\$2,000,000).

weeds (15\%), or plant growth regulation (16\%). The greater use of nonchemical insect control measures occurred in all regions of the country and for all size firms, indicating widespread adoption by the greenhouseand nursery industry. This speaks well for the efforts in nonchemical insect control, but indicates that much work is required to make similar progress in other areas. We have not had the sameuniversity and industry focus in the areas of disease control, weed control, and plant growth regulation. There have been isolated technologies or success stories, such as the use of DIF or light quality to control height (Faust et al., 1994). An encouraging aspect of the survey results is that the industry has demonstrated a willingness to adopt nonchemical control measures.

2) University programs can address the industry-identified limitations to implementation of nonchemical control measures. Two of the top three limitations to nonchemical pest control relate to theavailability of materials and biological agents and their effectiveness. Development of materials, procedures, or biological agents with proven effectiveness should be the primary focus of the initial research program. Although cost is always a consideration for commercial nursery operations, the respondents considered this theleast limiting factor. Perhaps theinitial effort should be on demonstrating the availability of an effectivenonchemical control measure. Subsequent efforts can focus on cost-reduction measures. Oncethealternativecontrol measure is developed, a substantial level of resources should be directed to the development of information regarding proper use. The lack of sufficient information on nonchemical control measures was the second highest rated limitation (Tables 7 and 8). Information transfer is one of the primary responsibilities of extension service programs. The survey results suggest that a successful IPM program will a) develop effective alternative control measures, b) develop and disseminate sufficient materials to explain fully the details of the alternative practices, and c) strive to minimize additional labor requirements in the complexity of the alternative practice, i.e., keep it simple.

3) Nursery and greenhouse operators rely heavily on other growers and trade journal articles for information on alternative pest management practices. One implication fortechnology transfer is that extension specialists/agents could focus on a few key nurserymen for pilot IPM programs. These core nurserymen would then facilitate technology transfer to other nurserymen. If research work is published only in scientific journals, it will reach a very small number of nurserymen
(16\% of respondents indicated use a lot or primary source, Table 10). For effective technology transfer, researchers also should consider publishing their work in trade journals. The extension service was the third highest rated source of information overall and had the highest percentage rating for "primary source of information". When we consider the role of extension servicepersonnel in theother sources of information, it appears that the extension service is a very viable and valued source of information on nonchemical pest control measures.

\section{Literature Cited}

Aylsworth, J.D. 1994. Getting in to the biological mode. Greenhouse Grower 12(1):96, 98.

Chadwick, A.E. 1994. Bugs find these orchids too hot to handle. Greenhouse Grower 12(8): 74, 76

Faust, J.E., S. Verlinden, and R.D. Heins. 1994. Pulsing Temps at Sunrise. Greenhouse Grower 12(1):82, 84-85.

Gill, S.A. and D.S. Ross. 1994. Insect microscreening: Its time has come. Greenhouse Grower 12(5):77, 80-82.

Table 11. Regional comparison of information sources about alternative pest management practices.

\begin{tabular}{|c|c|c|c|c|c|c|c|c|}
\hline \multirow[b]{3}{*}{ Source } & \multicolumn{8}{|c|}{ Use a lot/primary source } \\
\hline & \multicolumn{2}{|c|}{ Northeastern } & \multicolumn{2}{|c|}{ Southeastern } & \multicolumn{2}{|c|}{ North-central } & \multicolumn{2}{|c|}{ Western } \\
\hline & $\%$ & Rank & $\%$ & Rank & $\%$ & Rank & $\%$ & Rank \\
\hline Industry trade journals & 61.1 & 1 & 61.6 & 1 & 61.1 & 1 & 51.2 & 1 \\
\hline Cooperative extension service & 60.7 & 2 & 50.0 & 3 & 43.5 & 3 & 32.3 & 6 \\
\hline Industry-sponsored seminars & 44.0 & 4 & 44.9 & 4 & 43.2 & 4 & 50.0 & 2 \\
\hline University-sponsored seminars & 28.3 & 5 & 39.1 & 6 & 33.9 & 5 & 33.8 & 5 \\
\hline Private consultants & 11.5 & 7 & 15.6 & 8 & 12.8 & 8 & 23.6 & 7 \\
\hline Other growers in industry & 55.2 & 3 & 58.0 & 2 & 57.0 & 2 & 41.9 & 4 \\
\hline Scientific journals (HT, JEH) & 11.3 & 8 & 25.5 & 7 & 15.2 & 7 & 9.2 & 8 \\
\hline Chemical company representative & 25.7 & 6 & 39.6 & 5 & 27.6 & 6 & 44.1 & 3 \\
\hline
\end{tabular}


Gill, S. 1994. Take control with Bio-control. part 1. Greenhouse Grower 12(2):20, 22-24.

Heinz, K.M. and M.P. Parrella. 1993. Have you though about biological whitefly control?: Pesticidealternatives can saveyou money. Greenhouse Manager (Aug.):62, 64-66, 69.

Hodges, A. 1991. Business analysis of woody ornamental container and field nurseries in Florida, 1989. Fla. Coop. Ext. Serv. IFAS Circ. 954.

Hodges, A. and D. Hull. 1991. Business analysis of foliageplant nurseries in Central and South Florida, 1989. Florida Coop. Ext. Serv. IFAS Circ. 953.

Lawson, R.H. 1994. Silicon reduces Pythium losses. Greenhouse Manager 13(1):81-82.

Moody, J.T. and M.C. Halbrooks. 1992. An integrated pest management extension program for nursery producers in South Carolina. S. Nursery Dig. 26(9):29-30.

Oetting, R.D. 1994. IGRs for IPM. Greenhouse Grower 12(12):28-31.

Onofrey, D. 1994. Environmental controls leave fungi dry. Greenhouse Grower 12(13):32-33, 36.

Parrella, M.P. 1994. The future of pesticides in floriculture. GrowerTalks 57(10):21, 23, 25, 27, $29,31$.

Robb, K. 1994. Try new earth-friendly controls. Greenhouse Manager 13(1):77, 79-80.

Whitten, M. 1994. Profits could sink with no alternative to methyl bromide. Greenhouse Manager 12(12):90, 92-95.
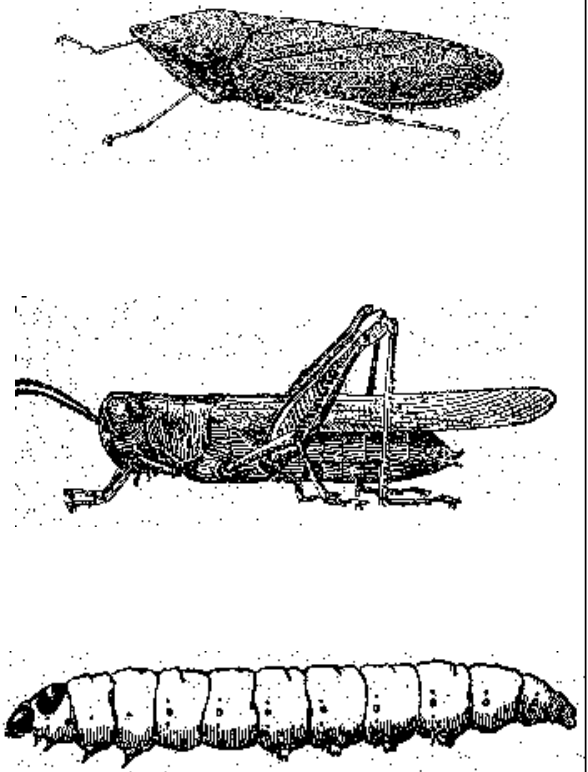

\section{Pest Management in the United States Greenhouse and Nursery Industry: II. Disease Control}

Ronald K. Jones ${ }^{1}$,
Ann R. Chase
Melvin P. Garber
,
William G. Hudson
,
Jeffrey G. Norcini ${ }^{5}$, and
Kane Bondari

Additional index words. fungicides, diseases, pesticides, biological control, alternative control, bactericides

Summary. A national survey of the commercial ornamental industry was conducted to determine the current status of pest control including chemical and nonchemical disease control practices. The fungicides thiophanate methyl, chlorothalonil, mancozeb, and metalaxyl were used in the greatest quantity and by

${ }^{1}$ Associate professor and extension plant pathologist, North Carolina State University, 2422 Gardner Hall, Raleigh, NC 27695-7616.

${ }^{2} E$ meritus professor of plant pathology, Central Florida Research and Education Center, University of Florida, Apopka, FL 32703.

${ }^{3}$ Associate professor and extension horticulturist, University of Georgia, P.O. Box 1209, Tifton, GA 31793

${ }^{4}$ Associate professor and extension entomologist, University of Georgia, P.O. Box 1209, Tifton, GA 31793

${ }^{5}$ Associate professor, University of Florida Research and Education Center, Route 4, Box 4092, Monticello, FL 32344-9304.

${ }^{6}$ Professor, Department of Statistical and Computer Service, Coastal Plain Experiment Station, Tifton GA 31793

The cost of publishing this paper was defrayed in part by the payment of page charges. Under postal regulations, this paper therefore must be hereby marked advertisement solely to indicate this fact. the largest percentage of growers.

Metalaxyl was used in greenhouse and field operations by the highest percentage of growers, primarily to control root diseases but many growers reported using metalaxyl to control foliar disease. Overall, more fungicides were used in the field for foliar diseases, whereas almost equal amounts of fungicides were used for foliar and root diseases in the greenhouse.

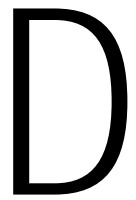

isease control methods have changed periodically over the years according to sociological and scientific developments. In the early 1900s, the ornamentals industry used many disease control methods based on cultural controls such as use of pathogen-free planting material (Murashige, 1974; Priapi, 1993), environmental manipulation, and a fewinorganic pesticides such as sulfur and copper used alone or in combination with lime to control diseases. During the 1960s, many new organic fungicides became available, which revolutionized disease control in the ornamentals industry. These fungicides were highly effective, active against a relatively narrow range of pathogens with low injury to crop plants, and easier to apply than previously available products. The use of these newer fungicides allowed higher-quality, lessexpensive plants to be distributed throughout the world.

During the past 10 years, improved environmental management techniques (Cuny, 1995) such as humidity control (Bartok, 1990; Onofrey, 1994), and light and temperature controls, especially with computerized systems (Pritchard and Flynn, 1993), have altered further the balance of pest control methods in the ornamental industry. Fungicide use patterns have continued to change during the past 5 to 10 years. Decreased, threatened or lost avail ability of standard industry chemicals such as methyl bromide (Whitten, 1994) dodemorph acetate and benomyl sometimes have forced a shift to less effective products or to nonchemical methods of pest control. New earthfriendly (Robb, 1994) products, such as silicon for Pythium control (Lawson, 1994), bicarbonates for powdery mildew control (Horst et al., 1992), horticultural oils (Steward, 1993), biorational (Triact) ,and biological (SoilGard) products (W.R. Grace\& Co., Grace BioControl, Columbia, Md.) currently are being researched and are labeled for use in the United States. At the same time, the industry has been confronted with pest resistance to some of the most commonly used products (Pommer and Lorenz, 1982; Roberts, 1994). Environmental regulations and USEPA Worker Protection Standards, such as reentry restrictions, have complicated further the use of pesticides on ornamentals. Finally, a dramatic shift in public opinion regarding 